\section{THE POLITICAL ECOLOGY OF ENVIRONMENTAL MANAGEMENT IN THE DEVELOPING WORLD}

\author{
Raymond L. Bryant \\ Department of Geography \\ King's College London, Strand \\ London, WC2R 2LS, UK
}

\section{LA POLÍTICA ECOLÓGICA Y LA GESTIÓN AMBIENTAL EN UN MUNDO EN DESARROLLO}

\begin{abstract}
RESUMEN: Este artículo aborda diversos aspectos clave de la gestión ambiental en el mundo en desarrollo desde la perspectiva de la ecología política. Comienza con un breve repaso de la evolución de la ecología política. Posteriormente se abordan dos casos de estudio en el Sudeste de Asia con el fin de explorar espacios de confrontación y espacios de cooperación que aglutinan elementos clave de la historia y la actualidad de la gestión ambiental en el mundo en desarrollo. En este proceso el artículo concluye que las multifacéticos políticas de transacción que tienen lugar en el mundo no pueden ser transformadas simplemente a través de apolíticas llamadas a "salvar la naturaleza".
\end{abstract}

PALABRAS CLAVE: Ecología política, mundo en desarrollo, gestión ambiental, espacios de confrontación y cooperación, Burma, Filipinas.

\section{INTRODUCTION}

No amount of wishful thinking by journalists, academics, celebrity environmentalists or other "do-gooders" will change one basic fact about human-environmental relations in the modern era: they are everywhere and always deeply politicised. The monumental violence and misery that humans have heaped on each other over time is inescapably etched on the biophysical environment - indeed, to the extent that it is socially constructed in ways that reflect unequal power relations. The spectacle of rich and famous people singing before a worldwide audience (as in London in July 2006) in order to "Save the Planet" reflects but does not alter this situation.

A political ecology approach seeks to understand environmental management in the developing world (an awkward label encompassing Africa, Asia and Latin America simply used for convenience here) by confronting its deadly nature. It does so not out of a sense of despair but argu-

\begin{abstract}
This paper addresses selected aspects of environmental management in the developing world through the prism of a political ecology perspective. It begins with a brief overview of the evolution of political ecology. It then turns to two case studies from SouthEast Asia in order to explore spaces of confrontation and spaces of cooperation - spaces that encompass key elements of historical and contemporary environmental management in the developing world. In the process, the paper underlines the multifaceted politics of transaction that takes place in a world that can never be transformed simply through apolitical calls to "save nature".
\end{abstract}

KEY WORDS: Political ecology, developing world, environmental management, spaces of confrontation and cooperation, Burma, Philippines. ably rather from a sense of hope - hope based on deeply ingrained scepticism about the motives of the powerful as well as a realisation that moves toward an ecologically sustainable and equitable future is predicated on the unflinching analysis of hurdles that first need to be surmounted.

This paper thus seeks to address selected aspects of environmental management in the developing world through the prism of political ecology. It first provides a brief overview of the development of the field of political ecology. It then turns to two case studies from South-East Asia in order to explore spaces of confrontation and spaces of cooperation that are believed to comprise important elements of the historical and contemporary dynamics of environmental management in the developing world (even while recognising that these elements are hardly "representative" of the great diversity of processes at play in such a vast entity). In the process, the paper underlines the multifaceted politics of transaction that takes place 
in a world that can never be transformed simply through "apolitical" calls to "save nature" - as if such a call was somehow detachable from the messy politics that has got nature "into trouble" in the first place.

\section{LocATing POLITICAL ECOLOGY}

Political ecology began life in the 1970s as a multi-disciplinary research field located at the juncture of anthropology and geography. Its origins lay in the analysis of rural areas of the developing world (or "Third World") and reflected deep disquiet about politically mainstream explanations of social and environmental change. Drawing on Marxism and dependency theories, scholars repudiated "neo-Malthusian" accounts that blamed environmental problems on runaway population growth among the poor (for overviews of political ecology, see Bryant and Bailey 1997; Watts 2000; Forsyth 2003; Robbins 2004). Instead, they put forward class-based analyses that emphasised structural political and economic inequalities at the heart of colonial and post-colonial capitalist relations that drained money and natural resources away from "peripheral" developing countries to "core" developed countries even as this process left local communities in the former highly vulnerable to recurrent "natural" hazards such as droughts and floods.

Marxist political ecology thus combined a preoccupation with the global capitalist system, the structural subordination of the "Third World" as a key part of that system, and the oppressiveness of class inequalities notably manifested in the form of highly unequal peasant-landlord agrarian relations. Major works of this period (which stretched from the 1970s through the late 1980s) included Piers Blaikie's (1985) landmark study on "the political economy of soil erosion", Michael Watts' (1983) historically based dissection of rural class relations in Nigeria, and Stephen Bunker's (1985) exhilarating juxtaposition of dependency and energetics theories to explain "underdevelopment in the Amazon". In this and other work, there was an effort to transcend prior work through a neo-Marxist "progressive contextualization" (or the move from looking solely at local biophysical changes to national and global social and economic causes and dynamics, see Vayda 1983). The strength of this approach was that it offered scholars a way to make sense of the power of "non-place-based" actors (such as trans-national corporations) over "placebased" actors (such as small-scale farmers). By combining an anthropological understanding of localities with neoMarxism's stress on class and developing world dependency on the developed world, writers sought to forge a truly political ecology approach to environment and development issues.

By the early 1990s, a new generation of scholars had become impatient with the economic "fixation" of early political ecology. In part, criticism reflected a widely perceived "impasse" in neo-Marxism - notably that it neglected to take seriously either the biophysical environment or non-economic issues (Booth 1994). In part, too, it reflected the concomitant rise of post-structural and post-Marxist thinking (linked to the likes of Foucault and Weber) which stressed more overtly political explanation. In practice, theoretical eclecticism was the order of the day - while some sought to "bring the State back in" others promoted a "feminist political ecology", while others still emphasised discourse analysis. The result was a field invigorated by much debate over the pathways and merits of the "post-structural turn" even as it led to (justified) complaints about a "lack of theoretical coherence" (Peet and Watts 1996).

Since the turn of the millennium, political ecology has continued to expand both in terms of the number of practitioners and in the array of topics and perspectives that it now encompasses (Forsyth 2003; Robbins 2004; Neumann 2005). In the process, it has continued to probe ever more deeply into the complex dimensions and properties of "politicised environments" in which state and nonstate actors interact over time and space and according to material and discursive imperatives. I now turn to the more detailed consideration of how such environments are intimately associated with both spaces of confrontation and cooperation.

\section{SPACES OF CONFRONTATION: TEAK AND THE BUILDING OF BURMA}

Political ecology is centrally concerned about the study of confrontation among actors seeking to manage the bio- 
physical environment. It has thus stressed the contested nature of environmental management - nowhere more so than in work on the developing world.

A key concern has been to assess the spatial interaction of states as they struggle over strategically important resources. The quest for oil, natural gas, timber, minerals and other resources remains a fertile source of conflict. Looming resource scarcities are only liable to intensify this situation. Teak has long played a role in this saga in a process that shaped not only how Burma - home to the world's best teak forests - related to other countries but also how other countries related to it. The resource that helped put Burma on the international map is also linked to economic policies of introversion and/or selective opening that have underpinned the image of Asia's "pariah" state. Attention to this case study is therefore useful to illustrate more generally how spaces of confrontation are created and with what ramifications.

If teak production helped to establish pre-colonial Burma as an important nation in regional flows of natural resources and wealth by the late eighteenth century, growing European (especially British) interest in the country helped to catapult Burma to the forefront of imperial geopolitics thereafter. Over a tumultuous sixty-year period, it was a prime focus of imperial action as the country was forcibly incorporated into the British-Indian Empire. The geopolitical fault line shifted in three stages as Britain seized successive portions of the country as a result of winning three wars: the first Anglo-Burmese war (1824$26)$, the second Anglo-Burmese war (1852), and the third Anglo-Burmese war (1885-86).

In each case, the imperial quest for teak played a role in shaping the move to war and the subsequent contours of empire. Thus, looming timber shortages associated with the depletion of oak supplies prompted British interest in Burma's plentiful teak forests in the early nineteenth century. A key problem from the British viewpoint was that the annual teak supply from monarchical Burma was erratic at a time when the British navy was demanding a reliable supply of timber for its shipyards in Calcutta (Pollack 1979). If the reasons for this supply problem varied over time - shifts in royal policy, domestic timber consumption, internal political battles, and so on - the result was an unacceptable state of affairs for the British.
As Anglo-Burmese relations deteriorated the British set their sights on the acquisition of Tenasserim - a coastal strip of land that was at the periphery of the Burmese Empire yet rich in teak. Following the first Anglo-Burmese war, the British set about exploiting the Tenasserim forests with timber firms pursuing cut-and-run policies in the absence of regulation. These forests were all but exhausted by the 1850s and the attention of firms thus shifted to the teak-bearing Pegu Yoma (or hills) of southern Burma still then under monarchical rule.

The second Anglo-Burmese war marked a more aggressive stage in British imperialism as Burma began to be seen as part of the British Indian Empire. Valuable teak forests were again an important consideration. On the one hand fears that unregulated extraction would simply repeat the disaster in Tenasserim thereby leaving Britain without adequate supplies provided one justification for war. On the other hand, when the war was concluded, British officials ensured that much of the Pegu Yoma was included in British-ruled areas (Pollack 1979). Such teak diplomacy was followed by the promotion of long-term exploitation under a forest department specifically created for this task in 1856 (Brandis 1859; Nisbet 1901).

And yet, once again, British military conquest did not result in the capture of the key teak forests that were north of the new border, along the Chindwin River and in the Shan States. Firms led by the British-owned Bombay Burmah Trading Corporation Limited (BBTCL) had already begun to snap up timber leases from a financially impoverished Burmese monarchy in 1862. Subsequent claims that the latter was sanctioning widespread deforestation (as well as an "unfair" fine imposed on the BBTCL by King Thebaw) provided a pretext for war (Geary 1886; Keeton 1974). For the British, it was important to seize upper Burma's teak forests before they were exhausted through "misuse" - ironically at a time when most forests in British-ruled lower Burma had already been cleared for permanent agriculture (Adas 1983). This calculation, when combined with fears over French designs on Burma, provided the basis for the third Anglo-Burmese war (Chew 1979).

In this way, British business and the British-Indian government brought Burma's teak forests - and with them the country itself - firmly into the British sphere. This process 
was as bloody as it was disruptive of pre-existing land and forest management among the people who depended on the forests. In the years that followed, the geopolitical dimensions and implications of the nineteenth century Anglo-Burmese conflict became clearer and were to prove remarkably durable.

Aside from formally defining the eastern edge of the British Empire in continental South-East Asia (until 1947), the Anglo-Burmese conflict led to a sharper definition of the territory of "Burma". Profound political and ecological implications followed from this territorial strategy that helped to shape both the internal and external policy environment as political power assumed a specific spatial form (cf. Storey 2001). In the process, Burmese environmental management has been played out in a geopolitical context itself that had been shaped by the quest for teak.

Two implications can be noted here. First, as the idea of Burma took shape under the British, that idea was linked to the notion that the country was a "natural" producer of abundant natural resources. As a world-leading rice exporter, Burma was also the world's key source of teak as well as being home to a variety of precious minerals including jade. The country thus became indelibly associated with the extraction of natural resources - its "free gift of nature" (Furnivall 1909). Second, as fixed borders replaced zones of influence, Burma's relations with its neighbors (notably Siam/Thailand, China and India) followed a new course even as old patterns of timber extraction and migration posed a challenge to regional relations. "Arbitrary" national borders did not necessarily mesh with pre-existing timber extraction routes let alone the migratory patterns and extended kin relationships of shifting cultivators and others who lived in the new border areas (Thongchai Winichakul 1994). Cross-border discontinuities were exacerbated by the practice of "divide and rule" whereby core Burman-dominated areas were under direct British rule while peripheral areas were subject to indirect rule via British-sanctioned hereditary local rulers (Taylor 1987). Peripheral autonomy among Burma's "ethnic minorities" under the British became a major bone of contention in the post-colonial era and intersected in complicated ways with center-periphery relations in neighboring countries.

Postcolonial Burma's geopolitical relations have continued to be shaped by teak-related concerns elaborated during the pre-colonial and colonial eras. One difference from the colonial era at least has been the Burmese practice of geopolitical introversion (albeit, combined with sporadic and selective opening) behind a "teak curtain" (Thawngmung 2004).

Geopolitical introversion was taken to an extreme after a coup d'etat in March 1962 brought General Ne Win and other military commanders to power. Between independence (January 4, 1948) and the 1962 coup, teak revenue had played a role in underpinning the Rangoon-based democratic government led by $U$ Nu even though revenue was severely limited due to pervasive violence in the forests. After 1962, teak revenue became ever more crucial to the fortunes of the Ne Win ruled state. Thus, whereas in 1951-52 teak exports accounted for only 4 per cent of the value of total exports (mainly rice and minerals) by 1970 that figure was 25 per cent (Trager 1954: 26; Steinberg 1981: 117). By 1984-85 the figure was 27.4 per cent but soared thereafter to as much as 42 per cent of the country's total official exports by value (Ministry of Planning and Finance 1985: 107; Smith 1991: 5; figures are estimates).

And yet, two things can be noted in relation to the post1962 politics of Burma's teak management. First, teak revenue provided a financial lifeline for a state beset by multiple insurgencies. Indeed, it was a key means by which the Ne Win regime mounted successful offensives against its foes (Smith 1999). Second, teak exports provided one of the few connections between Burma and the rest of the world during the Burmese Way to Socialism (1962-88). A powerful State Timber Board oversaw this trade and associated extraction and was answerable to Ne Win and associates (Forestal International 1978). In effect, teak earnings enabled the Burmese State to fashion a quasi-autarchy involving minimal political, economic and cultural links to the outside world in a classic case of geopolitical introversion.

Following the popular upheaval and brutal military crackdown of 1988, the military junta known as the State Law and Order Restoration Council (SLORC) shifted tack in a process in which timber exports (including teak) loomed large. The regime had little choice. On the one hand, the SLORC-ruled Burmese State was branded an international pariah by Western countries suddenly attentive to this 
"hermit state". On the other hand, a small but influential Burmese diaspora in Europe, North America and Australia campaigned actively against the SLORC and in favor of the imprisoned Burmese leader Aung San Suu Kyi - the winner of the country's only free and fair election held in a generation. The response by the SLORC was to develop links with its Asian neighbors - especially Thailand and China - using Burma's abundant natural resources (including teak) as a bargaining chip.

The political, economic and ecological details of the post1988 period in which Burma's military rulers embarked on an aggressive strategy of resource geopolitics are well documented (Geary 1994; WRI 1998; Global Witness 2003). Three things need to be highlighted about this process here. First, SLORC resource geopolitics ushered in a new and bloodier phase in the country's civil war as it fought its opponents with growing success. Teak and other resource earnings were vital as they enabled the SLORC to upgrade the capability of the army (tatmadaw) with improved weaponry bought from China. From the vantage of the SLORC, the teak/natural resource-military hardware nexus proved to be a virtuous cycle since acquisition of the latter enabled it to conquer more and more insurgent territory opening up profitable new extraction activities for the tatmadaw. For villagers caught in the midst of battles that raged across the country, consequences were devastating.

Second, SLORC resource geopolitics was about working to realign the political and economic interests of key neighbors such that they would become partners of the regime. In return for lucrative teak and other natural resource deals, Burma's leaders hoped to win the support of neighbors in debates over Burma held in the United Nations and other fora (e.g. ASEAN). The key players were Thailand (and ASEAN) as well as China and support was won through a process of exploiting regional rivalries. Such resource-related diplomacy led to closer ties with Thailand and other ASEAN countries (leading to Burma even joining the latter organization in 1997) and the opening up of the frontier between Burma and China as trade between these two sets of relations boomed (Geary 1994; Global Witness 2003).

Third, and related to this last point, SLORC resource geopolitics enabled the regime to neutralize the international influence of the Burmese opposition that had been a threat to it in the late 1980s. While that opposition has enjoyed support in Europe, North America and Australia, it has been less influential in Asian countries that matter to the SLORC: China, Japan and the ASEAN nations. Thus, Burma's poor human rights record since 1988 (it was bad before but less known) has prompted campaigns including boycotts against companies that work with the regime. Yet, the lack of international consensus - undermined by China, Japan and Thailand - ensured that the SLORC (now, State Peace and Development Council) has not felt political pressure in the way that other "pariah" states have (Seekins 1992; Global Witness 2003).

How teak geopolitics has directly led to battles for control of the teak forests is central to the spatial politics of Burmese environmental management. Resource militarization has long been associated with the quest for teak through a process that has produced a "violent environment" in which many lives have been blighted (cf. Peluso and Watts 2001). True, forest violence is not only associated with that quest - other resources have been at stake (such as tin and jade). Further, violence has also often been motivated by non-resource-related objectives, notably the crushing of opposition to the state (Smith 1999).

And yet, it would be odd indeed if economic incentives that influenced the geopolitics of British imperialism in the nineteenth century, and the geopolitics of regional trade in the late twentieth century did not have a major impact on the people who dwelt in the teak forests. In practice, that impact was often quite negative in terms of peoples' livelihoods and safety. Here, I examine resource militarization to underscore how the production of violent environments was part-and-parcel of the "scientific" management of teak forests.

Resource militarization reflected various processes even as it held diverse implications for forest dwellers. The transformation of the teak forests into violent environments was a variable process. Still, it was often associated with the politics of inter-ethnic strife and state versus opposition group conflict. The details are complex (see Taylor 1987; Smith 1999), so an overview will suffice here.

Teak forests have been hotspots in the long-standing production of violent environments. Indeed, they have 
long been home to those opposed to lowland rulers - "a traditional hiding-place for malcontents" (Foucar 1956: 72). Historical and contemporary accounts abound with descriptions of "bandits", "banditry" and battles in the forest as weaker protagonists retreated to areas into which powerful political groups were at a tactical disadvantage due to the terrain (Mills 1979; Adas 1982). A case in point occurred in the 1930s as the Hsaya San rebellion was centered on the teak-bearing Pegu Yoma and took the British years to quell (Maung Maung 1976). In other cases, "banditry" was more "home-grown", as residents mobilized against outsiders intent on disrupting their livelihoods - the Burma forest department was a focal point of such resistance. Clearly, the circumstances and protagonists varied over space and time. However, the capture of teak logs in the forest was a favored practice. As forests became "bandit country", though, residents were ensnared in fighting even though many were non-combatants. Violence and uncertainty was the norm as teak logs were seized in an opportunistic fashion.

Teak forests were also the focus of systematic military strategizing by well-organized insurgent armies intent on capturing an important source of revenue. The most notable case concerned the long-running insurgency by Karen and other ethnic minorities against the Burmancontrolled state that began soon after independence was attained in 1948 (Smith 1999; Global Witness 2003). Indeed, the fifty-year struggle by the Karen National Union (KNU) to establish Kawthoolei - a sovereign state of the Karen along the Thai-Burmese border - was partly reliant on teak revenue. This dependency was greatest after the 1960s as KNU forces were pushed back to the border by the tatmadaw. By the 1980s the KNU was even more reliant on such revenue to underpin the insurgency and a flourishing trade with Thai partners ensued (Falla 1991; Bryant 1997).

Still, the greatest impetus to resource militarization was the effort by successive rulers of the Burmese State to assert control over the teak forests. In pre-colonial times, this ability was limited. However, a series of organizational and technological innovations in colonial and post-colonial times meant that rulers since the mid-nineteenth century have often achieved greater forest control than before. In particular, the combination of modern armaments and systematic forest knowledge (courtesy of the forest department) were a boon for British and Burmese leaders keen to exploit the forests to the hilt (Adas 1982; Selth 1996; Bryant 1997).

Even then, teak exploitation was not easy. Central control was highly contingent and involved much danger for officials caught in the line of fire. The level of violence fluctuated over time. However, political upheaval and social unrest - especially in the late colonial (1920-1946) and post-colonial eras (since 1947) - were associated with extreme violence in the forests. Not surprisingly, state efforts to extract teak resembled a military campaign. Forest officials and/or private lessees would enter the forest only with armed escorts - sometimes to the dismay of foresters afraid that these escorts were "merely a succulent bait for the large bands of well- armed rebels roaming the country" (BOF 1946). In the mid-1950s, the U Nu government mounted a large-scale military operation - code named "Operation Teak" - in insurgent "infested" southern Burma. Units of the tatmadaw secured the banks of the Sittang River between Toungoo and Rangoon and provided river escorts for the rafts. Timber was rafted from the forests to Rangoon thereby earning the government precious foreign exchange (The Nation [Rangoon] November 10, 1955).

Such violence left a deep mark on people. Livelihoods were disrupted while residents were sometimes forced to take up arms, thereby inviting reprisals. The worst reprisals against forest dwellers occurred after 1962 as the tatmadaw killed, tortured and raped countless thousands of villagers suspected of helping insurgents. Many thousands of villagers have been forced to do dangerous work on behalf of the military (Smith 1999; Global Witness 2003).

A counter-insurgency campaign known as Pya Ley Pya ("four cuts") was at the core of this strategy. It targeted those who lived in or near to the forests and was designed to deprive insurgents of access to food, funds, intelligence and recruits (Smith 1999). In military terms, this campaign enabled the tatmadaw to achieve a series of victories against opponents beginning in the Irrawaddy Delta in the 1960s. The Four Cuts campaign was subsequently extended to the Pegu Yoma with Operation Aung Soe Moe conducted between 1973 and 1975 when the last insurgents were cleared from there. During the 1980s and 1990s, the campaign moved to northern and eastern 
border areas where, again, military success was achieved (Smith 1999; Global Witness 2003) and teak was an important part of SLORC strategizing.

Anti-insurgency campaigns of this sort were not new - the British mounted similar "pacification" campaigns in the late nineteenth century (Aung-Thwin 1985). However, the sheer scale and brutality of the post-1962 campaign stands out with entire villages moved to "secure" sites. In these sites, strict surveillance was imposed while displaced villagers faced a brutal forced labour regime (Doherty and Nyein Han 1994; Fink 2001). Extreme violence was thus the norm (BCN and TNI 1999; Tucker 2001). This campaign has been accompanied by rampant timber extraction that is eliminating the country's forests (Bryant 1997; Global Witness 2003).

The creation of spaces of confrontation and violent environments full of despair and death, as with the case just described, has been integral to a wider set of processes: colonialism, nationalism, international relations, militarisation, and globalisation. They are seemingly part of the warp and woof of modern life. Yet, there is also scope for the analysis of more hopeful spatial patterns of human-environmental interaction, albeit still conditioned by complex political interests and calculations.

\section{SPACES OF COOPERATION: NG0-GRASSROOTS DYNAMICS IN THE PHILIPPINES}

Political ecology has increasingly paid attention to the study of spaces of cooperation in which actors seek to assert new management practices vis-à-vis the biophysical environment. Moving beyond standard accounts of peasant resistance to landlords and the state, this work serves to emphasise how political strategizing in broad and flexible "alternative" coalitions is common in environmental management in many parts of the developing world today (Escobar 2001).

A key aspect here has been the strategic partnership between nongovernmental organizations (NGOs) and local "grassroots" organizations and movements. Yet the view that NGOs simply go into local communities as they choose and thereafter call the shots in that partnership is usually false - and represents a misunderstanding of power relations between these actors (Clark 1998; Bryant 2005). Indeed, as the following case study of Philippine NGO efforts to work with local communities illustrates, spaces of cooperation need to be based on mutual respect and trust as well as careful negotiations over the purpose and conditions of cooperation.

Indeed, local community support for an NGO can never be taken for granted. Political, economic and cultural divisions often render pan-community endeavors problematic. Other obstacles include local distrust, skepticism and hostility towards outsiders. NGO practices designed in turn to overcome these hurdles and facilitate work in communities can be here labelled constructive engagement. This process involves a campaign to convince potential partners of the local utility of the NGO. Why should residents work with them? Can NGOs keep their promises? Will there be longterm support to the community?

I relate two NGO experiences to address these questions. The first NGO is the Philippine Association for Intercultural Development (PAFID) - a small to medium size Manilabased organisation (of between 20 and 40 employees) that has worked for more than three decades on indigenous people's land and resource rights. Its experience with local communities on Coron Island in northern Palawan is specifically assessed here. The second NGO is the Haribon Foundation - a medium sized organisation (around 40-60 employees) that has been a leading environmental NGO in the Philippines since the 1970s. Its work with local residents at Mount Isarog in southern Luzon is considered briefly here.

The PAFID case illustrates how connections developed over time can lead to a durable relationship. The nature of the first contact is critical. In 1985, Coron Island barangay [district] councillor Rodolfo Aguilar approached PAFID after learning that it had helped another community to obtain a government Community Forest Stewardship Agreement (CFSA). Not perfect, this certificate seemed to be one means for islanders to repel unwanted development. The NGO was initially invited to Coron to explain the scheme. After much debate, a majority of residents supported the CFSA. With a letter of invitation from the Tagbanua (the local islanders), the NGO helped to create the Tagbanua Foundation of Coron Island (TFCI) and to prepare the CFSA 
application. The combination of the award of the CFSA in 1990, and the TFCl's maturation under Aguilar, meant that residents were able to reduce local development intrusions (Jaravelo and Tolentino 1989; PAFID 1998).

Yet TFCl authority required constant assertion. PAFID helped develop a management plan plus taught residents how to cultivate cashews for the market. Outsiders, meanwhile, once more threatened local control. Businesses took tourists to the lakes, beaches and clan caves that were a source of income (edible bird nests), water, and burial site. Individuals with government connections felled trees in violation of the CFSA. Coron Island was proposed as a site for a European Union biodiversity conservation scheme with backing from the Department of Environment and natural Resources (DENR) and big NGOs such as Conservation International. Migrant fishers and even some community members used dynamite or sodium cyanide to catch fish thereby destroying coral reef.

Residents turned again to PAFID for help. The NGO had won kudos for helping to create the TFCl and to win the CFSA. Subsequent ties were further proof of local commitment. This record was important in the organization's next phase of local involvement in the mid-1990s. PAFID agreed to help out once a letter of invitation from the residents was received. The importance of such a letter to the NGO in building spaces of cooperation is not to be gainsaid. It provides staff with an effective response to charges of meddling by those angry with the NGO. The letter insulates it against intra-community division. It strengthens the organization in the eyes of donors. Finally, the letter makes the symbolic but important point that the community is formally in charge of joint projects thereby according that community respect. Politically astute, the letter of invitation is also a testament to the reputation of an NGO such as PAFID.

If constructive engagement involves the generation of measurable outcomes, it is also about capacity building and knowledge dissemination. These processes may defy measurement but are important. Indeed, they can prompt changes in community perspectives with implications for social resistance and policy. PAFID involvement at Coron in the mid-1990s is illustrative here. In particular, confrontation over the EU-funded National Integrated Protected Areas Programme (NIPAP) emphasized the multifaceted behind-the-scenes influence of PAFID vis-à-vis the Tagbanua. It also becomes clear how the creation of spaces of cooperation can gain momentum as NGO assistance becomes critical to local community management choices.

Residents were uncertain about the NIPAP. True, the scheme promised the protection of Coron Island. Yet suspicion of official initiatives left many uneasy. Could proponents be trusted to account for Tagbanua concerns? How would NIPAP affect existing practices? How might acceptance of NIPAP impact on other quests, notably the one for official recognition of ancestral domain? PAFID played a key role in assisting them here. It did so notably by helping the TFCl to prepare a NIPAP consultation held on the island in October 1996. The meeting was designed to explain the NIPAP to residents. That it turned out differently was notably due to PAFID.

NGO employees were sceptical about NIPAP. They were familiar with it through work on the nearby island of Mindoro where indigenous people had rejected the scheme for fear that designation would undermine ancestral claims (NIPAP 1996; Rood 1998). Hence, PAFID leader Dave De Vera advised the TFCI to compile a list of local practices for a Tagbanua Ancestral Law. He suggested this step would bolster community pride since the Law profiled Tagbanua skills even as it would be a basis for a Certificate of Ancestral Domain Claim (CADC). The Law provided the TFCl with its own proposal to present at the consultation (TFCl 1996; PAFID 1998).

The Law was prepared by the TFCl with PAFID assistance. The process involved distilling oral traditions into a written account of locally "sustainable" land and water management. Logistical and intellectual support from PAFID was vital. A community organizer thus spent much of October doing this task. Not only did this employee transcribe the oral account into a manuscript. He also translated what was agreed into legal idiom amenable to official consideration. Much depended therefore on this employee's precision. Yet he was highly respected and trusted by a Tagbanua leadership accustomed to working with PAFID employees who "delivered the goods".

Other staff came to help as the date of the meeting neared. That two experienced policy analysts as well as leader De 
Vera turned up underscored the PAFID commitment. They assisted Belen and the TFCl with community validation of the Law and offered advice on strengthening it. They also made crucial interventions during the consultation itself. Thus, while the TFCI chaired the consultation, PAFID employees provided support from the sidelines. Prior to the start of the meeting, for example, De Vera met with the NIPAP leader to discuss Tagbanua problems with the NIPAP - especially the lack of local control of the proposed Protected Areas Management Board (PAMB) - and to ascertain where NIPAP stood on this matter. Staff helped Aquilar thereafter to ensure that audience participation reflected concerns about the protected area. Above all, organizing work paid-off when the NIPAP team failed to intimidate the Tagbanua. Local self-confidence was especially demonstrated on the second day of the consultation when the TFCl completed their critique of the NIPAP proposal and presented their own Ancestral Law without hitch.

What to make of PAFID's role here? The NGO was central to the process of articulating a Tagbanua perspective. While the Ancestral Law reflected the views of the Tagabanua, PAFID helped them to see how it could be used strategically to promote ancestral domain over the NIPAP scheme. Yet the stakes were high as it was suggested that the Tagbanua would "no longer" be poor if they accepted the latter. However, because they had faith in PAFID, they rejected such blandishments in favor of action suggested by the NGO.

Such trust reflected bonds of friendship developed with PAFID staff over the years. In the case of the community organizer Ruel Belen, local acceptance was solidified through his residency on the Island. Yet acceptance reflected more than the activities of one employee. Various staff had visited Coron since 1985. Trust and friendship thus extended to others as well. This process also reflected a conscious effort: "our first activity was to establish immediate rapport with the community" (Jaravelo and Tolentino 1989: 1). This effort took various forms including sport. To nurture connections in this way was vital to constructive engagement between PAFID and the Tagbanua. Indeed, how staff conducted themselves with community members was often as important as what goals they achieved. This is not surprising since communities (like the Tagbanua) are beset by elites disdainful of them
(Rood 1998; Lawrence 2002). Thus, to create spaces of cooperation requires, above all, respectful conduct on the part of NGOs to local partners.

The experience of the Haribon Foundation at Mount Isarog in southern Luzon provides further evidence to this effect. It also alerts us to the manner in which constraints on an NGO can lead to the degradation of such a space. This NGO became involved in this region in 1989 when students working for Haribon did a survey of the local national park. Systematic work began when funding was obtained thereafter. Five barangay were selected for a conservation project based on criteria linked to human settlement in the park, extent of environmental destruction, road accessibility, provision of government services, and the peace and order situation (Communist insurgents were still locally active). Employees assigned to each barangay were responsible for community organizing, alternative livelihoods and research. Haribon entered these districts without a letter of invitation. Employees instead held "house-to-house conferences" where they introduced themselves and explained what biodiversity conservation was and why it was needed. They also set out the community-based management approach that they wished to see introduced. This method was labour-intensive but vital if the NGO was to connect with communities.

Local circumstances were not propitious since many communities were dependent on illegal logging. As the leader of the Cawaynan people's organization recalled, when the NGO arrived, people conducted uillegal logging, kaingin [shifting cultivation] and other forest extraction as a major source of livelihood" (Vale 1996). Members of local government were involved in illegal logging and bitterly opposed Haribon. While the NGO was able to organize in Cawaynan, the leaders of that people's organization were thereafter locked "in conflict with the local government" (Vale 1996). In Panicuason, Haribon fared worse as local opposition torpedoed a people's organization. Endemic poverty was also a factor. Many people were dependent on landlords who were indifferent to the Haribon message. In Lugsad, ninety percent of the 160 families were tenants growing crops such as sugarcane who were also reliant on forest extraction - there was little room for maneuver here. Appeals to them of the merits of conservation thus fell on deaf ears at first. 
Progress was still made. People's organizations were created with each organization comprising between twenty and thirty members. These organizations bore the stamp of the NGO inasmuch as they were identically structured via committees. Soon, the day-to-day activities of the committees reflected the input of residents keen to advance their interests through the new institutions. Here too, Haribon was vital. Its staff provided leadership training and accountancy skills to enable the organizations to function. They offered para-legal training to facilitate the fight against loggers even as employees taught ecology and agroforestry to promote alternative livelihoods.

Haribon earned local respect through these activities. The manner in which Haribon entered the community was important since house-to-house conferences helped employees learn about local concerns in a respectful manner. The alternative livelihood scheme in particular signaled that the NGO understood the need to combine talk of conservation with practical steps to promote livelihoods. The focus was on agroforestry with each people's organization given funds to develop seed nurseries and demonstration farms. The nurseries would increase the supply of woody and fruit tree species so that people involved in logging could safely abandon that practice. The farms would do likewise but would also illustrate sustainable farming methods designed to appeal to tenants and landlords.

Yet the scheme had a negligible impact on livelihoods. Bad luck was partly to blame as a typhoon ripped through the area destroying seedlings and devastating crops. Still, the modest nature of the scheme meant that it could only ever have a minor impact. On the one hand, there was "easy money" from logging. As one resident observed, "if the project can guarantee livelihood [in contrast to logging] I support it but I doubt it" (Riipinen 1995: 55). On the other hand, there was ongoing dependency on landlords. The head of the Lugsad people's organization had to clear forest owned by his landlord for a sugarcane plantation but could not challenge him for fear of dismissal (Perez 1996).

Haribon still won local support. In Lugsad, residents appreciated the provision of education on sustainable farming and agroforestry. One participant explained, "I have learned much on new planting techniques and forest conservation through this project» (cited in Riipinen 1995:
54). The leader of the Cawaynan people's organization reflected a general view in observing that residents "now understood the value of protecting their forest" against clear felling it for immediate gain thanks to the hard work of Haribon staff (Vale 1996). On the one side, there was a recognition that valuable biodiversity was being lost. On the other, there was the prospect of new economic activities predicated on in situ conservation. Recognition of the virtues of the project was summarized by a villager: "This does not help us to change everything but it helps us to get some more income to the organization, and through this we can get some benefits to us, as well as to the environment» (in Riipinen 1995: 53-54).

Haribon earned kudos by joint action against illegal loggers - a dangerous practice that risked violence. Yet such action was an «integral part of Haribon's work» (Luna 1996). Staff helped the Lugsad organization, for example, to erect a human barricade across a road used by loggers. This move stopped a shipment and thereafter greatly reduced local logging. Success also gave an enormous boost to the people's organization since it seemingly demonstrated their power. Finally, it was a boon to Haribon, as it demonstrated the value of its work and a willingness to show solidarity with local partners even under duress.

These interventions did not win the battle against illegal logging at Mount Isarog. Their cumulative effect, though, did contribute to its decline. Reporters noted this impact in assessing Haribon's role. Thus, Doris Gaskell Nuyda (1997) writing in the Philippine Daily Inquirer described the fall in logging as a "success story" in the national environmental battle in which local groups "contained" the threat with firm support from Haribon.

Yet Mount Isarog was no clear-cut success for Haribon. Funding was a headache. Thus, the NGO suffered a severe budget cut locally in 1994 that led to the loss of eight of ten project employees. Project success was jeopardized since, as project officer Noel Resurrecion (1996) observed, they "pulled out too soon" from the communities. While external forces were to blame, the pullout nonetheless generated tension between staff and local organizations. One local leader (anonymously) explained that he and his colleagues experienced difficulty "ever since the Haribon Foundation has left them on their own". Indeed, he added, it had "left them too early" as they were not ready "to take 
organizational responsibilities all by themselves». There was resentment too that only six months notice was given and no extension was granted despite local appeals.

There were knock-on effects. The pullout triggered a decline in local interest in the people's organization as residents had looked to Haribon for guidance. True, the impact varied between barangay. In Lugsad, the people's organization flourished since a new micro-finance project was initiated with Haribon assistance. Also, this group enjoyed strong leadership from residents who doubled as district officials. That said, even here, there were "organizational problems" following the pullout.

Haribon staff worked hard to contain the fallout that was apparently damaging this space of cooperation. They knew that their name was sullied even though they were not to blame for the budget cuts. However, NGOs often face local frustration at such times due to an expectation that staff can fix problems (Alegre 1996; Fowler 1997). Haribon thus pursued several avenues to repair the damage. They persuaded the four people's organizations to form an umbrella group, the Anduyog Federation, to fill the gap left by Haribon even as staff helped it to win funding. A micro-lending project was followed by a capacity building grant from the Foundation for the Philippine Environment related to community organizing, seed propagation, lobbying and fundraising. These actions softened the blow of the pullout. They also underscored Haribon's ongoing commitment to local partners even in the face of budget cuts. Representatives of the local groups, meanwhile, sought to understand the situation and make do under the new circumstances.

As the Haribon experience in particular suggests, constructive engagement is not an easy process. Community support must be constantly earned through interaction in which NGOs demonstrate competency and solidarity. This is not straightforward even under ideal conditions. Support often wanes when NGOs do not keep promises. As such, the ability not only to create but thereafter to maintain spaces of cooperation requires great skill as links must be continuously cultivated and trust perpetually reinforced.

\section{Conclusion: political eCOLOGY tRANSACtions}

This paper has drawn on two case studies (both drawn from South-East Asia) in order to explore selected aspects of the political ecology of environmental management in the developing world. There is, of course, no attempt in this paper at being "representative" of the sorts of issues and problems that shape such management. That would indeed be a hopeless task in such a vast and variegated area as the "developing world". Nonetheless, I have sought to draw out at least some of the dynamics and implications of such management, at least when seen from a political ecology perspective.

Specifically, I have explored environmental management in the developing world analytically in terms of "spaces of confrontation" and "spaces of cooperation". This approach to a vast topic enables us to pinpoint how unequal power relations - which are a core concern of political ecology - relate to the spatial behaviour of actors, notably through the creation of geographies of despair and hope. Clearly, these geographies change over time and are, in any case, perceived differently by different actors. This is to say that environmental management is inescapably political - the great drama of human life on Earth is, after all, a drama long preoccupied with conflict and cooperation over how to manage the environment and even more crucially who is to do so. For those who work towards a more "sustainable" future for human-environmental interaction, therefore, political understanding and engagement is an essential prerequisite for effective action. In the process, a messy and multifaceted politics of transaction is unavoidable. 
Recibido: 19 de septiembre de 2007 Aceptado: 15 de octubre de 2007

\section{REFERENCES}

Adas, M. (1982): "Bandits, Monks, and Pretender Kings: Patterns of Peasant Resistance and Protest in Colonial Burma, 1826-1941", in Power and Protest in the Countryside, R. P. Weller and S. E. Guggenheim (eds.), pp. 75-105 (Durham, NC: Duke University Press).

Adas, M. (1983): "Colonization, Commercial Agriculture, and the Destruction of the Deltaic Rainforests of British Burma in the late nineteenth century, in Global Deforestation and the Nineteenth Century World Economy, R. P. Tucker and J. F. Richards (eds.), pp. 95-110 (Durham, NC: Duke University Press).

Alegre, A. (ed.) (1996): Trends and Traditions, Challenges and Choices. (Manila: Ateneo Center for Social Policy and Public Affairs).

Aung-Thwin, M. (1985): "British «Pacification" of Burma: Order without Meaning", Journal of Southeast Asian Studies 16: 245-61.

Blaikie, P. (1985): The Political Economy of Soil Erosion in Developing Countries (London: Longman).

Booth, D. (ed.) (1994): Rethinking Social Development (London: Longman).

Brandis, D. (1859): Rules for the administration of forests in the province of Pegu (Rangoon: Superintendent of Government Printing and Stationery).

Bryant, R. L. (1997): The Political Ecology of Forestry in Burma (Honolulu: University of Hawaii Press).

Bryant, R. L. (2005): Nongovernmental Organisations in Environmental Struggles (New Haven: Yale University Press).

Bryant, R. L. and Bailey, S. (1997): Third World Political Ecology (London: Routledge).

BCN (Burma Center Netherlands) and TNI (Transnational Institute) (1999): Strengthening Civil Society in Burma: Possibilities and Dilemmas for International NGOs (Chiang Mai: Silkworm Books).

BOF (Burma Office Files) (1946): "Confidential note on illicit extraction of timber and general lawlessness", Conservator of Forests, Sittang Circle, 8 May.

Chew, E. C. T. (1979): "The Fall of the Burmese Kingdom in 1885: Review and Reconsideration", Journal of Southeast Asian Studies 10: 372-80.

Clarke, G. (1998): The Politics of NGOs in South-East Asia: Participation and Protest in the Philippines (London: Routledge).

Doherty, F. and Nyein Han (1994): Burma: Human Lives for Natural Resources - Oil and Natural Gas (np: Southeast Asian Information Network).

Escobar, A. (2001): "Culture sits in Places: Reflections on Globalism and Subaltern Strategies of Localisation", Political Geography 20: 139-74.

Falla, J. (1991): True Love and Bartholomew: Rebels on the Burmese Border (Cambridge: Cambridge University Press).

Fink, C. (2001): Living Silence: Burma under Military Rule (London: Zed Books).

Forestal International Limited (1978): Forest Feasibility Study: Forest Resources, vol. 1 (Rangoon: Government of Burma).

Forsyth, T. (2003): Critical Political Ecology (London: Routledge).

Foucar, E. C. V. (1956): I Lived in Burma (London: Denis Dobson).

Fowler, A. (1997): Striking a Balance (London: Earthscan).

Furnivall, J. S. (1909): "Land as a Free Gift of Nature", Economic Journal 19: 552-62.

Geary, G. (1886): Burma after the Conquest (London: Sampson, Low, Marston, Searle and Revington).

Bunker, S. G. (1985): Underdeveloping the Amazon (Urbana, III.: University of Illinois Press).
Geary, K. (1994): The Role of Thailand in Forest Destruction along the Thai-Burma 
Border 1988-1993 (Bangkok: Project for Ecological Recovery).

Global Witness (2003): A Conflict of Interests: The Uncertain Future of Burma's Forests (London: Global Witness).

Jaravelo, F. and W. Tolentino (1989): "Travel Report: Coron Island, February 25 to March 2, 1989" (Manila: PAFID).

Keeton, C. L. (1974): King Thebaw and the Ecological Rape of Burma: the Political and Commercial Struggle between British India and French Indo-China in Burma, 1878-1886 (Delhi: Manohar).

Lawrence, K. (2002): "Negotiated Biodiversity Conservation for Local Social Change: A Case Study of Northern Palawan, Philippines" (Unpublished PhD Thesis. London: Department of Geography, King's College London).

Luna, M. P. (1996): Tanggol Kalikasan Program Coordinator, Haribon Foundation, Manila, 30 October [personal interview].

Maung Maung (1976): "Nationalist Movements in Burma, 1920-1940: Changing Patterns of Leadership: From Sangha to Laity" (Canberra: MA thesis, Australian National University).

Mills, J. A. (1979): "Burmese Peasant Response to British Provincial Rule 18521885", in Peasants and Politics: Grass Roots Reaction to Change in Asia, D. B. Miller (ed.), pp. 77-104 (London: Edward Arnold).

Ministry of Planning and Finance (1985): Report to the Pyithu Hluttaw on the financial, economic and social conditions of the Socialist Republic of the Union of Burma for 1985-86 (Rangoon: Government of Burma).

The Nation [Rangoon] November 10, 1955.

National Integrated Protected Areas Program (NIPAP) (1996): Annual Report for 1996 (Manila: NIPAP).

Neumann, R. P. (2005): Making Political Ecology (London: Hodder Arnold).
Nisbet, J. (1901): Burma under British Rule and Before (London: Archibald Constable).

Nuyda, D. G. (1997): "Haribon Scores a Victory for the Environment", Philippine Daily Inquirer, 7 March.

Peet, R. and Watts, M. (eds.) (1996): Liberation Ecologies: Environment, Development, Social Movements (London: Routledge).

Peluso, N. L. and Watts, M. (eds.) (2001): Violent Environments (Ithaca: Cornell University Press).

Perez, D. (1996): Chairperson, Anduyog Federation and Captain, Barangay Lugsad, Naga City, 15 October [personal interview].

PAFID (Philippine Association for Intercultural Development) (1998): Mapping the Ancestral Lands and Waters of the Calamian Tagbanwa (Manila: PAFID).

Pollack, O. B. (1979): Empires in Collision: Anglo-Burmese Relations in the midNineteenth Century (Westport, CT: Greenwood Press).

Resurrecion, N. (1996): Project Officer and Community Organizer, Haribon Foundation, Naga City, 14 October [personal interview].

Riipinen, P. (1995): Making an Alternative Living in the Philippines (Helsinki: Finnish Philippine Society).

Robbins, P. (2004): Political Ecology: A Critical Introduction (Oxford: Blackwell).

Rood, S. (1998): "NGOs and Indigenous Peoples" in Organizing for Democracy, ed. G. S. Silliman and L. G. Noble, pp. 138-56 (Honolulu: University of Hawaii Press).

Seekins, D. M. (1992): "Japan's aid relations with military regimes in Burma, 19621991", Asian Survey 32: 246-62.

Selth, A. (1996): Transforming the Tatmadaw: the Burmese Armed Forces since 1988 (Canberra: Australia National University).

Smith, C. F. (1991): Report on the Myanma Forestry Sector (Yangon [Rangoon]:
Union of Myanmar for the Food and Agriculture Organization).

Smith, M. (1999): Burma: Insurgency and the Politics of Ethnicity, $2^{\text {nd }}$ edition. (London: Zed Books).

Steinberg, D. I. (1981): Burma's Road toward Development (Boulder, CO: Westview Press).

Storey, D. (2001): Territory: the Claiming of Space (Harlow: Pearson).

Tagbanua Foundation Coron Island (TFCI) (1996): "Ancestral Domain Management Plan" (N.p.: mimeo).

Taylor, R. H. (1987): The State in Burma (London: C. Hurst).

Thawnghmung, A. (2004): Behind the Teak Curtain: Authoritarianism, Agricultural Policies and Political Legitimacy in Rural Burma (London: Kegan Paul).

Thongchai Winichakul (1994): Siam Mapped: a History of the Geo-body of a Nation (Honolulu: University of Hawaii Press).

Trager, F. N. (1954): Toward a Welfare State in Burma (New York: Institute of Pacific Relations).

Tucker, S. (2001): Burma: The Curse of Independence (London: Pluto Press).

Vale, Ronnie (1996): Chairperson, Samahang Pangkalikasan ng Cawaynan (SPC), Naga City, 14 October [personal interview].

Vayda, A. P. (1983): "Progressive Contextualisation: Methods for Research in Human Ecology", Human Ecology 11: 265-81.

Watts, M. (1983): Silent Violence: Food, Famine and Peasantry in Northern Nigeria (Berkeley: University of California Press).

Watts, M. (2000): "Political Ecology" in E. Sheppard and T. Barnes (eds.), A Companion to Economic Geography, pp. 257-74 (0xford: Blackwell).

WRI (World Resources Institute) (1998): Logging Burma's Frontier Forests: Resources and the Regime (Washington, DC: WRI). 